\title{
PHYSICOCHEMICAL CHARACTERISTICS AND FATTY ACID COMPOSITION OF TOMATO SEED OILS FROM PROCESSING WASTES
}

\author{
P.R. CANTARElli; M.A.B. REgitANO-d'ARCE; E.R. PALMA \\ Dep. de Ciència e Tecnologia Agroindustrial da ESALQ/USP - Caixa Postal, 9 - CEP: 13418-900-Piracicaba,SP.
}

\begin{abstract}
The major component of tomato processing industry wastes is seed. Samples of tomato (Petomech var.) pomace from industries of São Paulo state submitted to IIot and Cold Break treatments, were spontaneously fermented and washed to separate seeds. The oils were analysed for specific gravity, iodine and saponification numbers, refractive index, viscosity and fatty acid composition. Except for saponification number, Hot and Cold Break seed oils were very similar. In both treatments palmitic acid was the major saturated fatty acid, followed by stearic acid. Linoleic acid was the major unsaturated fatty acid foilowed by oleic acid. Both oleic and linoleic acids added up to over $60 \%$ of total fatty acids, being higher in Cold Break seed oils. Both treatments produced high nutritional oil quality. Differences in colour and viscosity may incur in more intense refining operations for Brazilian tomato processing industries due to the adoption of the IIot Break treatment.
\end{abstract}

Key Words: Tomato seed oil, fatty acid composition, physicochemical characteristics, industrial wastes.

\section{CARACTERÍSTICAS FÍSICO-QUíMICAS E COMPOSIÇÃO EM ÁCIDOS GRAXOS DE OI.EOS DE SEMENTES DE TOMATE DE RESÍDUOS INDUSTRIAIS}

RESUMO: O principal componente de resíduos da industrialização de tomates $€$ a semente. Amostras de resíduos após extração comercial de tomates maduros (var. Petomech) submetidas a tratamentos de Ilot e Cold Break em indústrias do Estado de São Paulo foram deixadas fermentar espontaneamente e as sementes separadas após lavagem. Os óleos foram analisados quanto ao peso específico, índices de iodo e saponificação, índice de refração, viscosidade e composição em ácidos graxos. À exceção do índice de saponificação, os bleos dos tratamentos Ilot e Cold Break apresentaram-se semellantes. Em ambos os tratamentos o principal ácido graxo saturado foi o ácido palmítico, seguido pelo ácido esteárico. $O$ ácido linoléico foi o principal ácido graxo insaturado, seguido pelo ácido oléco e juntos somaram a mais de $60 \%$ do total de ácidos graxos, o que torna o b́leo de tomate recomendável à alimentação humana. As diferenças em cor e viscosidade dos b́leos podem implicar num processo de refino mais severo para os óleos do tratamento IIot Break utilizado pelas indústrias brasileiras.

Descritores: Gleo de sementes de tomate, composição em ácidos graxos, características físico-químicas, resíduos industriais.

\section{INTRODUCTION}

The expanding tomato processingindustry has been facing severe economical and technical environmental problems with the handling and disposal of resulting wastes. About one third of the total tomato production of 2.8 million tons goes to the industry for processing. The major component of such wastes is seed whose composition has been studied by several researchers (GAD et al., 1968; TSATSARONIS; BOSKOU, 1975; KRAMER; KWEE, 1977b; CANELLA et al., 1979; BRODOWSKI; GEISMAN, 1980; LAZOS; KALATHENOS, 1988; CANTARELLI et al., 1989), with data ranging from 14.6 to $29.6 \%$ crude fat; 14.8 to $41.8 \%$ crude fibre; 2.0 to $9.6 \%$ ash; 2.9 to $5.4 \%$ carbohydrates and 22.9 to $36.8 \%$ crude protein. The protein fraction presented suitable functional and nutritional properties (KRAMER; KWEE, 1977a,b; CANELLA; CASTRIOTA, 1980; LATLIEF; KNORR, $1983 a, b)$. The lipid fraction showed a high degree of unsaturation, with up to $55 \%$ linoleic acid (LAZOS; KALATHENOS, 1988).

The purpose of this work was to determine the fatty acid composition and some physicochemical characteristics of the oils extracted from industrial tomato seed wastes and evaluate its potential for human consumption.

\section{MATERIAL AND METIIODS}

Three samples of $10 \mathrm{~kg}$ tomato pomace were obtained after the commercial extraction of 
ripe tomatoes (cultivar Petomech) grown in São Paulo State, Brazil, which were submitted to Hot Break $\left(95^{\circ} \mathrm{C} / 10 \mathrm{~min}\right)$ or Cold Break $\left(60^{\circ} \mathrm{C} / 10 \mathrm{~min}\right)$ treatments. The samples, after a spontaneous fermentation at room temperature for ca. one week, were washed with tap water to separate seeds from skins and gelatinous material. The seeds were dried at $45^{\circ} \mathrm{C}$ for $48 \mathrm{hr}$ in a forced air oven, and then comminuted with a grinder model 4-E (Quaker City Mill, Pa).

Seed oils were extracted with $n$-hexane (boiling point $68-70^{\circ} \mathrm{C}, 6 \mathrm{hr}$ ) in a Soxhlet extractor, and stored in glass vials at $1-5^{\circ} \mathrm{C}$. Methyl esters of the fatty acids of the tomato oils were prepared according to LUDDY et al. (1960). The gas chromatographic analysis was perfomed with a C.G. 37-D Gas-Chromatograph (C.G. Scientific Instr., Brazil) fitted with a single stainless steel column (200 X $0.95 \mathrm{~cm})$ packed with 18\% Diethyleneglycol succinate (DEGS) on Chromosorb P A/W DMCS and flame ionization detector. Operating conditions were as follows: column temperature, $170^{\circ} \mathrm{C}$; detector temperature, $250^{\circ} \mathrm{C}$ : injector temperature, $210^{\circ} \mathrm{C}$ and nitrogen flow rate, $50 \mathrm{ml} / \mathrm{min}$.

Fatty acid identification was based on chromatograms of known standards and by the Equivalent Chain Length Mcthod. Pcak arcas wcre measured by triangulation.

Oil characteristics, namely specific gravity, iodine and saponification numbers, were performed according to standard methods (Associtation of Official Analytical Chemistry, 1975). Refractive index was detcrmined by Abbé refractometer at $20^{\circ} \mathrm{C}$. The viscosity was determined with an Epprechet viscosimeter model TVB (Contraves Inf. Products, England). All data represent mean values of three determinations not exceeding $\pm 5 \%$ variation.

\section{RESULTS AND DISCUSSION}

The fatty acid composition is presented in TABLE 1. Saturated, short-chained fatty acids except for stearic and behenic acids presented lower contents in the Cold Break seed oil.

Oleic and linoleic acid contents were higher in the Cold Break seed oil, while linoleic acid content was lower than that in the Hot Break seed oil.

Total saturated fatty acid content was higher in the Hot Break seed oil while total unsaturated fatty acid content was higher for the Cold Break seed oil.

On a percentage basis, it is known that such thermal treatments provide different yields of oil contents (CANTARELLI et al., 1989), i.e. 19.0 and $14.5 \%$ for Cold and Hot Break treatments, respectively. Therefore one could suppose there has been a differential leaching of oil (stearic and oleic acids being the most affected) and other components (protein, amino acids and carbohydrates) during the Hot Break treatment as shown in the previous work.

In both treatments, palmitic acid was the major saturated fatty acid, followed by stearic acid. Linolcic acid was the major unsaturated fatty acid followed by oleic acid. This data is in accordance with BERTONI et al. (1963); GAD et al. (1968); TSATSARONIS; BOSKOU (1972); VIGO et al. (1977); CANELLA et al. (1979) and LAZOS; KALATHENOS (1988). The differences in individual contents of fatty acids when compared to the literature, may be due to the cultivars used and to the cultivation and/or environmental factors.

All major fatty acids have been identified by many authors (BERTONI et al., 1963; AMELOTTI et al., 1967; GAD et al., 1968; TSATSARONIS; BOSKOU, 1972; VIGO et al., 1977; CANELLA ct al., 1979; EL-TAMIMI ct al., 1979 and LAZOS; KALATHENOS, 1988).

As can be obscrved from TABLE 2, except for the saponification number, Hot and Cold Break sced oils were very similar. Compared to other authors' data they can be included within the range of values reported. The levels found were in agreement with CANELLA ct al. (1979), who worked with the same cultivar (Petomech). They showed a high degrec of unsaturation and the presence of long chain fatty acids.

Cold Break seed oil was clearer golden yellow in colour and less viscous, $57.5 \mathrm{cP}$ at $25^{\circ} \mathrm{C}$, than the Hot Break seed oil which presented a darker red color and $61.0 \mathrm{cP}$ viscosity at the same temperature. Brazilian tomato processing industries use the Hot Break treatment for enzymic inactivation which would mean more intense refining operations to obtain a commercial oil quality.

\section{CONCLUSIONS}

The present work confirms previous information by CANTARELLI et al. (1989) that 
TABLE 1. Fatty acid composition of tomato seed oils (\%)

\begin{tabular}{lcc}
\hline \hline \multicolumn{1}{c}{ Fatty Acid } & Cold Break Seed Oil & Hot Break Seed Oil \\
\hline Lauric C12:0 & trace & 0.3 \\
Myristic C14:0 & 1.5 & 2.3 \\
Palmitic C16:0 & 16.9 & 23.4 \\
Stearic C18:0 & 9.5 & 4.0 \\
Arachidic C20:0 & 0.8 & 1.3 \\
Behenic C22:0 & 0.7 & trace \\
TOTAL SATURATED & 29.4 & 31.3 \\
Myristoleic C14:1 & trace & trace \\
Palmitoleic C16:1 & 3.3 & 6.8 \\
Oleic C18:1 & 29.7 & 18.3 \\
Linoleic C18:2 & 37.6 & 42.8 \\
Linolenic C18:3 & trace & 0.7 \\
TOTAL UNSATURATED & 70.6 & 68.6 \\
\hline \hline
\end{tabular}

TABLE 2. Some physicochemical properties of tomato seed oil.

\begin{tabular}{lcccc}
\hline \hline Property & $\begin{array}{c}\text { Specific } \\
\text { Gravity }\end{array}$ & $\begin{array}{c}\text { Refractive } \\
\text { Index }\end{array}$ & $\begin{array}{c}\text { Iodine } \\
\text { Number }\end{array}$ & $\begin{array}{c}\text { Saponification } \\
\text { Number }\end{array}$ \\
\hline \multicolumn{1}{c}{ Author } & & & & \\
Bertoni et al. (1963) & 0.9135 & 1.4721 & 116.5 & 191.4 \\
Canella et al. (1979) & - & 1.4714 & 130.5 & - \\
Cavalcanti (1941) & 0.9206 & 1.4771 & 112.6 & 192.1 \\
El-Tamimi et al. (1979) & - & - & 116.9 & - \\
Gad et al. (1968) & - & 1.4623 & 106.8 & 194.0 \\
Rios (1954) & 0.9357 & 1.4764 & 117.8 & 194.9 \\
Vigo et al. (1977) & 0.9138 & 1.4722 & 119.2 & 191.2 \\
Lazos; Kalathenos (1988) & - & 1.4577 & 105.0 & 190.0 \\
This work: & & & & \\
Hot Break & 0.9186 & 1.4733 & 126.4 & 164.8 \\
Cold Break & 0.9181 & 1.4720 & 126.1 & 156.0 \\
\hline \hline
\end{tabular}


indicates that tomato seed wastes are a potential source of edible oil. They should not be discarded as a fertilizer or animal feed due to the high unsaturated fatty acid content of the oils, whether they originate from Cold or Hot Break treatments of the ripe tomatoes. They are good sources of the essential linoleic fatty acid.

\section{REFERENCES}

AOAC Official methods of analysis. $12 \mathrm{ed}$. Washington: Association of Official Analytical Chemists, 1975.

AMELOTTI, G.; GARCIA, V.; FEDERICO, L.G. La composizione acidica di alcuni oli vegetali. Rivista Italiana delle Sostanze Grasse, Milano, v.44, p.372378, 1967.

BERTONI, M.H.; SUTTON, G.K.; CATTANEO, P. Argentine tomato seed oils; chemical composition. Anales de la Associacion Quimica Argentina, Buenos Aires, v.51, n.2, p.149-157, 1963.

BRODOWSKI, D.; GEISMAN, J.R. Protein conten and amino acid composition of protein of seed from tomatoes at various stages of ripeness. Journal of Food Science, Chicago, v.45, p.228-35, 1980.

CANELLA, M.; CARDINALLI, F.; CASTRIOTTA, G.; NAPPUCCI, R. Chemical properties of the seeds of different tomato varieties. Rivista Italiana delle Sostanze Grasse, Milano, v.56, n.1, p.8-11, 1979.

CANELLA, M.; CASTRIOTTA,G. Protein composition and solubility of tomato seed meal. Lebensmittel Wissenschaft und Technologie, Zurich, v.13, n.1821, 1980.

CANTARELLI; P.R.; PALMA, E.R.; CARUSO, J.G.B. Composition and amino acid profiles of tomato seeds from canning wastes. Acta Alimentaria, Budapeste, v.18, n.1, p.13-18, 1989.

CAVALCANTI, P.B. Óleo de semente de tomate. Revista Brasileira de Química Industrial, v.10, n.114, p.21-23, 1941.

EL-TAMIMI, A.H.; MORAD, M.M.; RAOF, M.S.; RADY, A.H. Tomato seed oil. I. Fatty acid composition, stability and hidrogenation of the oil. Fette Seifen Anstrichmittel, Berlim, v.81, n.7, p.281-284, 1979

GAD, A.M.; EL-KHALAFY, H.M.; HASSAN, M.M.; SHOEB, Z.E. Chemical investigations on Egyptian vegetable fats and oils. XIII. The chemical constitution of some Rosaceae, Solanaceae and Oleaceae seed oils. Grasas y Aceites, Sevilla, v.19, n.4, p.139-145, 1968.

KRAMER, A.; KWEE, W.H. Functional and nutritional properties of tomato seed protein concentrate. Journal of Food Science, Chicago, v.42, p.207-211, 1977a.

KRAMER, A.; KWEE, W.H. Utilization of tomato processing wastes. Journal of Food Science, Chicago, v.42, p.212-215, $1977 \mathrm{~b}$.

LATLIEF, S.J.; KNORR, D. Tomato seed protein concentrates: Effects of methods of recovery upon yield and compositional characteristics. Journal of Food Science, Chicago, v.48, p.1583-1586, 1983a.

LATLIEF, S.J.; KNORR, D. Effects of chitin as coagulating aid protein yield, composition and functionality of tomato seed protein concentrates. Joumal of Food Science, Chicago, v.48, p.1587. $1590,1983 \mathrm{~b}$.

LAZOS, E.S; KALATHENOS, P. Composition of tomato processing wastes. International Joumal of Food Science and Technology, Chicago, v.23, p.649-652, 1988

LUDY,F.E.; BARFORD, R.A.; RIEMENSCHNEIDER, R.W. Direct conversion of lipid components to their fatty acid methyl esters. Journal of the American Oil Chemists'Society, Chicago, v.37, p.447-451, 1960.

RIOS, E.C. Composição química de algumas variedades de tomates. Anais da Associação Brasileira de Química, Rio de Janeiro, v.13, p.5-13, 1954.

TSATSARONIS. G.C.; BOSKOU, D.G. Oils and fats. Fatty acid composition of tomato seed oil. Journal of the Association of Official Agricultural Chemists, Washington, v.55, n.3, p.645-647, 1972.

TSATSARONIS. G.C.; BOSKOU, D.G. Amino acid and mineral salt content of tomato seed and skin waste. Joumal of the Science of Food and Agriculture, London, v.26, p.421-423, 1975.

VIGO, M.S.; DASSO, I.; CATTANEO, P. Siudies on the seeds remaining after the processing of tomatoes. Anales de la Academia de Ciências Exactas, Físicas y Naturales, v.29, p.193-203, 1977.

Trabalho entregue para publicação em 19.02.92

Trabalho aprovado para publicação em 08.06 .92 